----- Raf. Jou. Sci., Vol. 22, No.2 pp 39- 49, $2011-----$

\title{
Preparation of Potassium Dicitro Bismuthate Complex as Antigastric Ulcer
}

\author{
Amer A. Taqa \\ Department of Dental Basic Science \\ College of Dentistry \\ Mosul University \\ E-mail: amertaqa@hotmail.com
}

(Received 28/11/2010; Accepted 21/2/2011)

\begin{abstract}
The present study was designed to synthesis potassium dicitro bismuthate (III) complex. The complex was characterized by infrared spectra, conductivity and elemental analysis of $\mathrm{Bi}$. The effect of gastro protection was investigated for the prepared complex against HCl- ethanol induced ulcer in rats. The complex was administered to rats at 50 and $100 \mathrm{mg} \mathrm{kg}$ doses orally before one hour of receiving $0.2 \mathrm{ml}$ of $\mathrm{HCl}$ - ethanol mixture to induce gastric ulcer. Sucralfate (100mg $\backslash \mathrm{kg}$, orally) was used as standard drug. The severity of gastro mucosal damage induced by $\mathrm{HCl}$-ethanol was analyzed in term of ulcer index value. Administration of potassium dicitro bismuthate (III) one hour before $\mathrm{HCl}$-ethanol had significantly decreased ulcer index value when compared to saline treated group. Sucralfate $(100 \mathrm{mg} \backslash \mathrm{kg}$, orally) also produced a significant decrease in ulcer index when compared with the saline treated group. There was no significant difference between potassium dicitro bismuthate (III) and Sucralfate in degree of protection against ulcer. Thus it can be concluded that potassium dicitro bismuthate (III) has antiulcer activity in rats.

Keywords: citric acid, bismuth complex, antigastric ulcer, Sucralfate
\end{abstract}

\section{تحضير مشقد ثلالثي بوتلسيوم شائيستريت البزموث والني يستخعم كمضاد الفرحة المحة}

\section{الملغص}

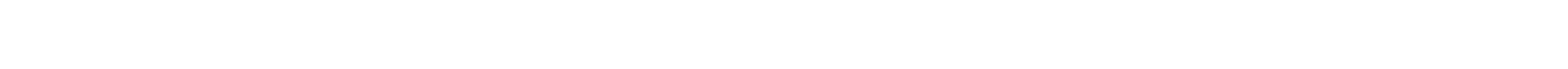

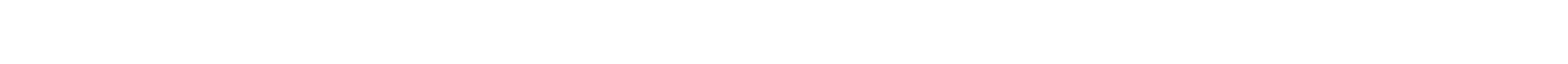

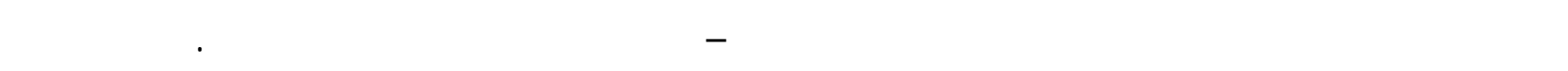

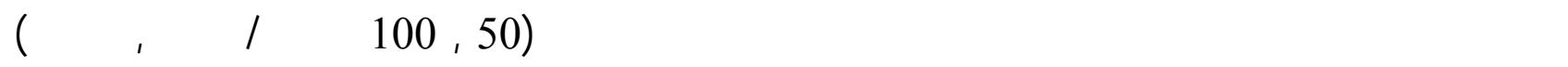
قلبساعة من اعطاء مزيج الايثانول - حلمض الهايدروكلوريك أدى إلى إحداث انغخف اض معن -وي ف في قalcer index

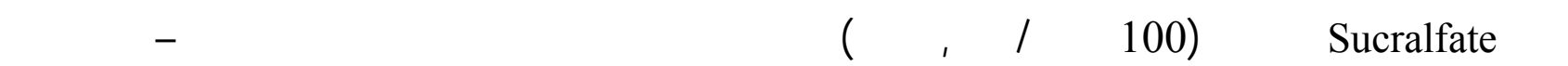




\section{الهايدروكلوريد إلى إحداث انغفاض معنوي في alcer index مقارنة بمجموعة اللسطرة. فمن هذه الدرلس ة

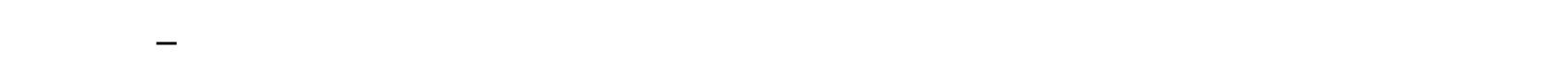 الهايدروكلوريك في الجرذان لذا فمن الممكن لستخدلمه للمنع الإصابة بالقرحة.}

\section{INTRODUCTION}

The importance of citric acid (CA) in abiotic and biological systems has been well established over the years (Ali et al., 2008, Carla et al., 2008, Tselesh, 2008, Maria et al., 2008). The nature of the metal-citrate complex formed depends upon the nature of the metal, the $\mathrm{pH}$ of the solution, type of coordination bond and the stoichiometric ratio of metal to citric acid.

Citrate is an important biological ligand for metal ions. It is present at high concentration (ca. $200 \mathrm{mM}$ ) in blood plasma and forms strong complexes not only with natural metal ions such as $\mathrm{Ca}^{\mathrm{II}}, \mathrm{Mg}^{\mathrm{II}}$ and $\mathrm{Fe}^{\mathrm{III}}$, but also with ions of toxic (e.g. $\mathrm{Al}^{\mathrm{III}}$ ), ( Petrova et al., 2008) therapeutic (e.g. $\left.\mathrm{Bi}^{\mathrm{III}}\right)$ and diagnostic (e.g. $\left.67 \mathrm{Ga}^{\mathrm{III}}\right)$ importance.

Peptic ulcer, one of the most widespread disease, is believed to be due to imbalance between aggressive and protective factors (Alkofahi and Atta, 1999) in the stomach such as acid-pepsin secretion, mucosal barrier, mucous secretion, blood flow, cellular regeneration, prostaglandin, epidural growth factor (Govindarajan et al., 2006, Lima et al., 2006) bacterial products (Helicobacter pylori) and drugs (Peskar and Maricic,1998). The current medical treatment of peptic ulcer is generally based on the inhibition of gastric acid secretion by $\mathrm{H}_{2}$ as Omeprazol and antimuscarinics, as well as, the acid in depended therapy provided by Sucralfate and bismuth (Bighett et al., 2005). Potassium dicitro bismuthate (III) has a topical action in the upper gastrointestinal tract (Coghill and Shepherd, 1988) and it is commonly used to treat a variety gastrointestinal disorder (Lourence and Keith, 2008). Potassium dicitro bismuthate (III) precipitate (an active metabolite) when it is reaches the acidic environment of the stomach (Wagstaff et al ., 1988).

The aim of the present study is to prepare potassium dicitro bismuthate (III) complex and characterize by molar conductivity, infrared spectra, and elemental analysis and its effect as antiulcer activity in experimentally induced ulcer in rats.

\section{MATERIALS AND METHODS}

All the materials (BDH) were used without any further purification.

\section{Preparation of Bismuth complex}

The complex was prepared by adding bismuth nitrate $(1 \mathrm{mmole})$ in $25 \mathrm{ml}$ of deionized water to an aqueous solution of citric acid $(2$ mmole) with continued stirring until a white precipitate was formed. The precipitate was washed with a small amount of deionized water. Bismuth citrate was suspended in $(25 \mathrm{ml})$ of deionized water, sodium carbonate powder was added with stirring until the solution become neutral. Absolute alcohol was added to the solution with stirring until a white precipitate was formed; the product was washed with $10 \mathrm{ml}$ of dry ether and dried (yield $80 \%$ ). Melting point more than $350^{\circ} \mathrm{C}$, molar conductivity $\left(345,125 \mathrm{ohm}^{-1} \mathrm{~cm}^{2} \mathrm{~mole}^{-1}\right)$ in water and ethanol, respectively.

Physical measurements: The FT-IR were measured as $\mathrm{KBr}$ disc by using FT-IR Spectrometer (Fourier transform infrared spectroscopy) (Bruker 27, TENSOR, Germany). 
Molar conductance was obtained approximately $10^{-3} \mathrm{M}$ in a Jenway conductivity meter model 4070. Content of Bismuth was determined by the following method (Malairajan et al., 2008). Moisten about $0.5 \mathrm{~g}$, accurately weighed with sulphuric acid, ignite at a temperature not exceeding $500^{\circ} \mathrm{C}$, and dissolve the product in $2 \mathrm{ml}$ of nitric acid and $4 \mathrm{ml}$ of water, add $50 \mathrm{ml}$ of glycerol and $0.2 \mathrm{~g}$ of sluphuric acid, allow to stand for one minute, and add $200 \mathrm{ml}$ of water and $0.3 \mathrm{ml}$ of catechol violet solution; if a violet color is produced add dilute ammonia solution, drop wise, until a blue color is produced; titrate with $\mathrm{M} / 20$ sodium edentate until a yellow color is produced; each $\mathrm{ml}$ of $\mathrm{M} / 20$ sodium edentate is equivalent to $0.01045 \mathrm{~g}$ of Bi.

\section{Pharmaceutical study}

Healthy rats of either sex weighing 200-250 gm were selected for this study. The animals were housed and fed with standard diet and water. Animals were deprived of foot at least 24 hrs. before starting of the experiment but were allowed free access to water. The rats were divided into 4 groups, each group consists of five animals. Group 1 served as a saline control and was given normal saline $0.9 \%(1 \mathrm{ml} / \mathrm{kg}$, orally), group 2 received (100 $\mathrm{mg}$ $/ \mathrm{Kg}$, orally) sucralfate (Alma company, Syria) as standard control. Group 3and 4 received $(50,100 \mathrm{mg} / \mathrm{Kg}$, orally) potassium dicitro bismuthate (III), respectively. After one hour all the animals were treated with $0.5 \mathrm{ml}$ of $\mathrm{HCl}$-ethanol mixture, orally $(0.3 \mathrm{M}$ hydrochloric acid and ethanol 60\%) to induce gastric ulcer. Animals were sacrificed by cervical dislocation, one hour after administration of $\mathrm{HCl}$-ethanol mixture (Malairajan et al., 2008). The stomachs were removed, opened along the greater curvature and examined for lesion severity, lesion severity was determined by measuring ulcer index, by measuring each lesion in mm along its greater length (Singh et al., 2008, Abay and Abdulwahib, 2008). The ulcer lesions observed were scored according to the severity according to previous study (Nwafor et al., 1996).

\section{Histological evaluation}

Sections of tissue from stomach were examined histologically to study ulcerogenic and or antiulcerogenic activity of tripotassium dicitro bismuthate (III). The slides were examined microscopically (Olympic Company) for pathomorphological changes such as congestion, hemorrhage, edema and erosion using an arbitrary scale for the assessment of severity of these changes (Al-Howiriny et al., 2005)

\section{Histopathological studies}

The stomach tissues were removed from the rats and fixed in $10 \%$ normal saline for at least 48 hrs. These were then processed routinely and the tissues were embedded in paraffin wax. Histological sections were cut at $5-6 \mu \mathrm{m}$ and stained with routine haematoxylin and eosin (HE). These were then examined by a histopathologist. The lesions observed were assessed for the following, mucosal atrophy, and the presence of inflammatory cells in the wall, oesinophils, lymphocytes and plasma cells. These were graded according to mild $(+)$, moderate $(++)$ or severe $(+++)$. Photomicrographs of representative lesions were taken at various magnifications.

\section{Statistical analysis}

The data were expressed as mean \pm SD, difference between three experimental groups were statistically analyzed by one way analysis of variance ( ANOVA) followed by the least significant difference test. The level of significance was at $\mathrm{p}<0.05$. 


\section{RESULTS AND DISCUSSION}

A- Structure assignment

\section{Fourier transform-infrared spectroscopy (FTIR)}

The following factors affect metal-ligand stretching vibrations: i) oxidation state of the metal atom, ii) coordination number and symmetry, iii) coordination bond strength, iv) the base strength of the ligand, and, v) bridging ligands.

\section{Citric acid}

The structure consists of two methylenic carbons $\left(\mathrm{CH}_{2}\right)$, three carboxylic acid $(\mathrm{COOH})$ groups, and a tertiary alcohol group $\left(\mathrm{C}_{3} \mathrm{C}-\mathrm{OH}\right)$. The sharp peak at $3500 \mathrm{~cm}^{-1}$ is due to $\alpha$ hydroxyl $\mathrm{O}-\mathrm{H}$ stretching, reflecting intermolecular hydrogen bonding. A broad group of bands between 3300 and $2500 \mathrm{~cm}^{-1}$ is due to $\mathrm{O}-\mathrm{H}$ stretching vibrations resulting from hydrogen bonding indicating a dimeric structure. The $\mathrm{C}-\mathrm{O}$ stretching vibrations for the alcoholic group occur at 1140, 1175, 1210, and $1240 \mathrm{~cm}^{-1}$. Carboxylic acid dimer peaks are indicated at 1350 to $1290 \mathrm{~cm}^{-1}$ and at $940 \mathrm{~cm}^{-1}$ due to $\mathrm{C}-\mathrm{O}$ stretching vibrations. The primary $\mathrm{C}=\mathrm{O}$ stretching vibration for $\mathrm{COOH}$ groups is seen as a doublet peak at $1740 \mathrm{~cm}^{-1}$ and $1710 \mathrm{~cm}^{-1}$. The split structure signifies the non-equivalence between the two terminal carboxylates and the central carboxylate group. The sharp peak at $1430 \mathrm{~cm}^{-1}$ manifests the tertiary alcohol in-plane $\mathrm{O}-\mathrm{H}$ stretching vibrations, while the moderately broad peak at 935 $\mathrm{cm}^{-1}$ is due to the dimeric carboxylic acid $\mathrm{O}-\mathrm{H}$ out-of plane stretching vibration(Dimitr et al., 2002).

potassiumdicitro bismuthate (III) complex

The association of a hydroxide group in metal bonding is indicated by the absorption peak at $3610(\mathrm{O}-\mathrm{H})$ and the $\mathrm{C} \alpha-\mathrm{OH}$ stretch is reflected in the peaks at 910, 850, and 830 $\mathrm{cm}^{-1}$. Complexation of the $\alpha$-hydroxyl group of citric acid is indicated by the absence of a peak at $3500 \mathrm{~cm}^{-1}$ compared to citric acid. Additional evidence for the association of the $\alpha$ hydroxyl group is indicated by the shift in the $\mathrm{C}-\mathrm{O}$ bending vibrations of the hydroxyl group to higher energies $\left(1190,1230,1260,1300 \mathrm{~cm}^{-1}\right)$ compared to those in citric acid. Lattice water is indicated by the shoulder peak at $3380 \mathrm{~cm}^{-1}$. Involvement of the citric acid carboxylate groups with the metals is suggested by the asymmetric $\mathrm{C}=\mathrm{O}$ stretching peaks at 1640 and $1570 \mathrm{~cm}^{-1}$. The position of these peaks is strong indication of unidentate as well as bidentate coordination to the metal. The shift in the symmetric $\mathrm{C}=\mathrm{O}$ stretch (medium) to $1440 \mathrm{~cm}^{-1}$ signifies bidentate or bridging carboxylate coordination, while unidentate coordination is confirmed by the peak at $1360 \mathrm{~cm}^{-1}$. The presence of a sharp peak at 1790 $\mathrm{cm}^{-1}$ is due to the $\mathrm{C}=\mathrm{O}$ stretch of the free carboxylate group(Dimitr et al., 2002).

The molar conductivity measurement: A high value of molar conductivity for the reflects complex has a 1:3 ratio of metal to ligand in both solvents. These results suggested a structure of complex Fig.1, the suggested structure was further confirmed by metal content analysis of bismuth (calculated;29.665, found 30.01\%) 


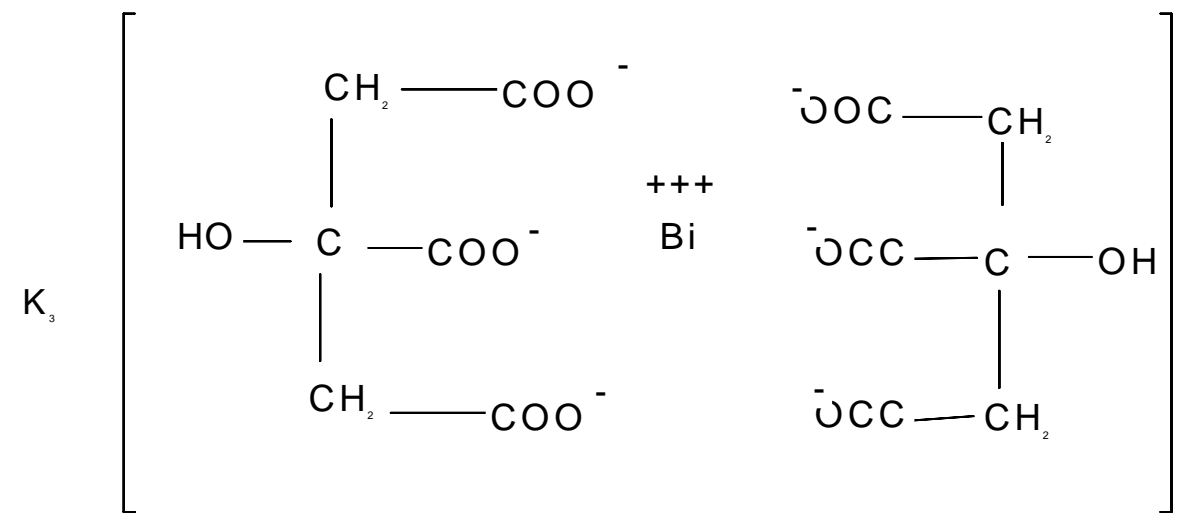

Fig. 1: The suggested structure for tripotasium dicitro bismuthate (III) complex.

B- Antiulcer activity of the complex

In the present study, the potassiumdicitro bismuthate (III) was evaluated for its antiulcer activity against $\mathrm{HCl}$-ethanol induced gastric ulcer in rat. Oral administration of $\mathrm{HCl}-$ ethanol produces sever ulceration, potassium dicitro bismuthate (III) at $(50,100 \mathrm{mg} / \mathrm{Kg}$, orally ) as well as standard drug Sucralfate at $(100 \mathrm{mg} / \mathrm{Kg}$, orally) significantly reduce lesion score of ulcer in comparison to saline treated group (Fig. 2,3,4).

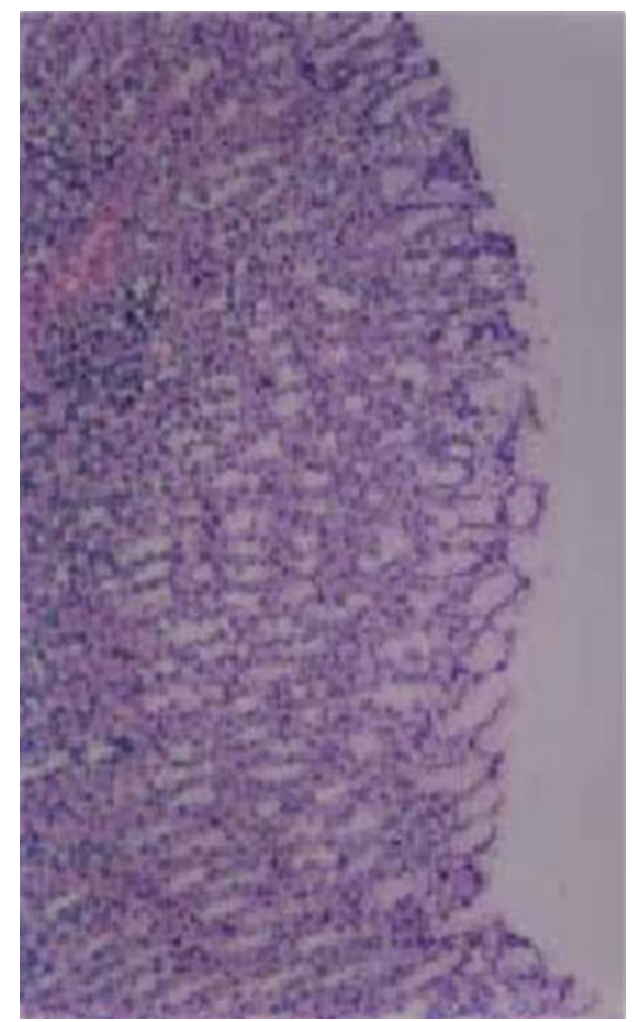

Fig. 2 : Showing normal appearance for section of gastric mucosa (H\&E. x100). 


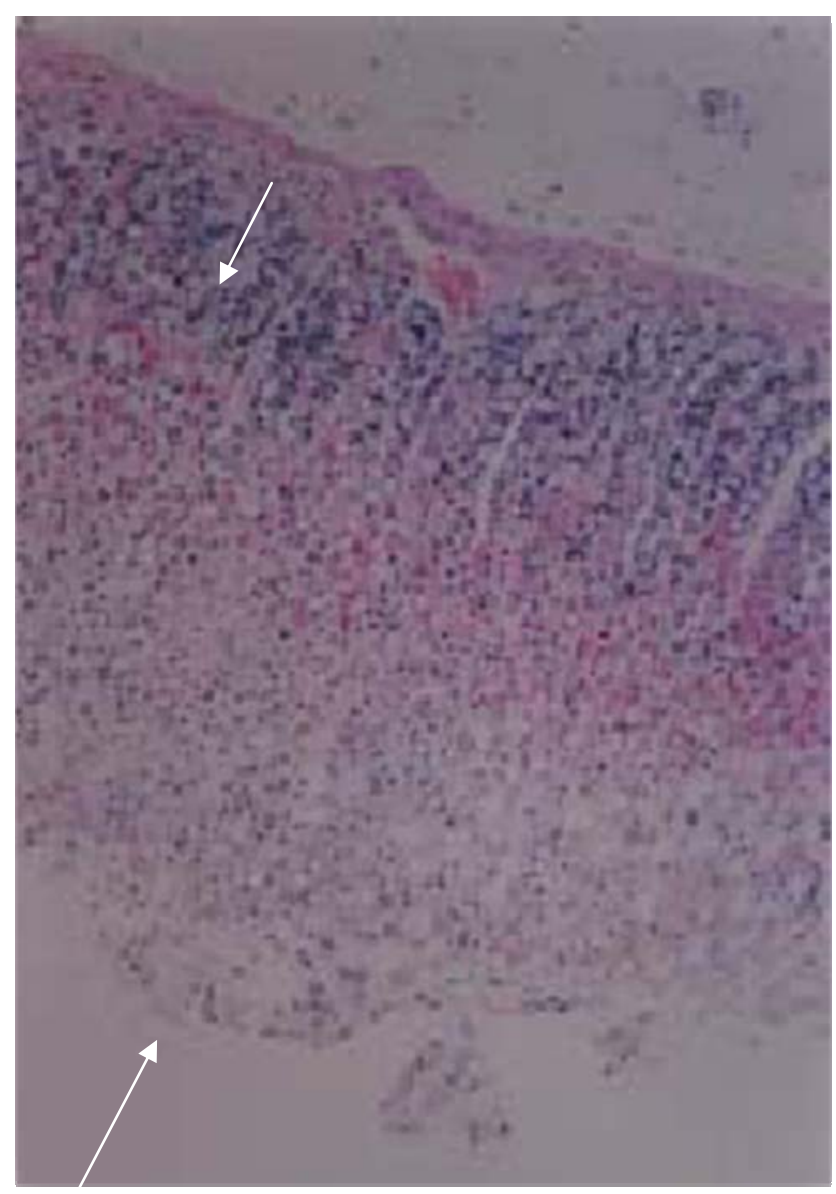

Fig. 3 : Section of gastric mucosa after treated with ethanol-HCl, showing inflammation, hemorrhage and mucosal ulceration. (H\&E.x100) .

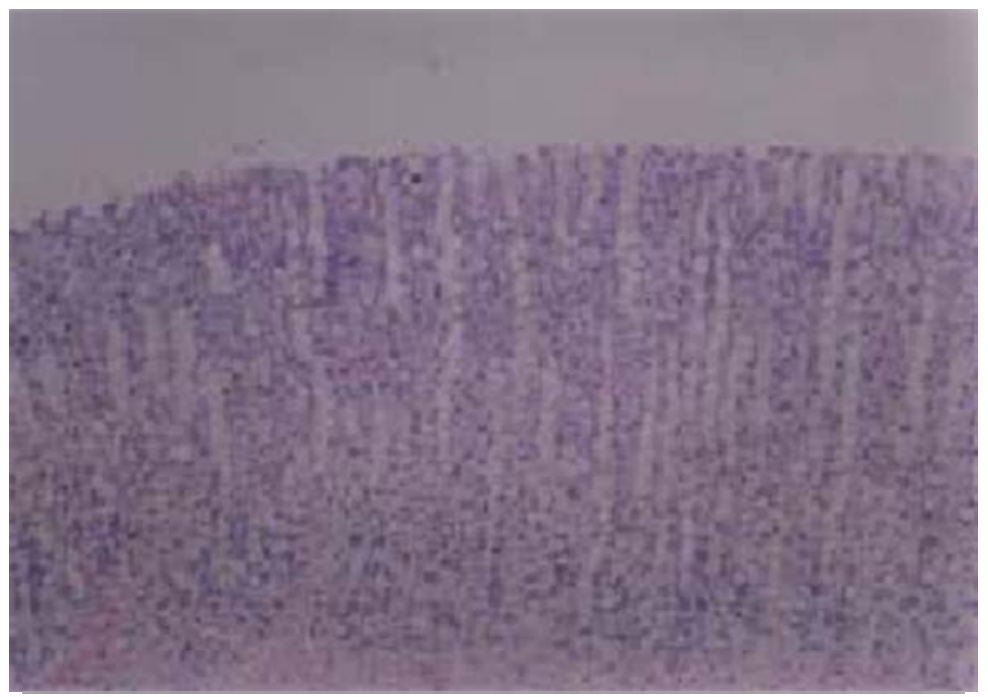

Fig. 4 : Gastric mucosa after treated with potassiumdicitro bismuthate (III) complex (H\&E. x100). - value are mean + SE 5 rat /group . Significantly different from the control group. $\mathrm{P}<$ 
Sever heamorrhagic lesions were found in the stomachs exposed to $\mathrm{HCl}$-ethanol, the mean lesions area in saline treated group $\left(7.44 \mathrm{~mm}^{2}\right)$ was significantly reduced in potassiumdicitro bismuthate (III) treated groups $(50,100 \mathrm{mg} / \mathrm{Kg}$ ) and Sucralfate $(100 \mathrm{mg}$ $/ \mathrm{Kg})$ to $(1.39,0.45) \mathrm{mm}^{2}$ and $(0.45) \mathrm{mm}^{2}$, respectively (Fig. 5) .

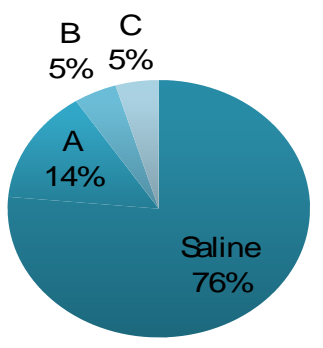

Fig. 5 : Effect of tripotassiumdicitro bismuthate (III) $(50,100 \mathrm{mg} / \mathrm{kg}$, orally) and Sucralfate (100 mg / Kg ,orally ) on lesion score on HCL-Ethanol induced gastric ulcer in rat - Value are mean \pm SE 5 rat /group.

(A) potassiumdicitro bismuthate (III) $50 \mathrm{mg} / \mathrm{Kg}$, (B) Sucralfate $100 \mathrm{mg} / \mathrm{Kg}$, (C) potassium dicitro bismuthate (III) $100 \mathrm{mg} / \mathrm{Kg}$.

Potassiumdicitro bismuthate (III) treated groups have shown significant percentage protection $(74.67 \%, 91.2 \%)$ at $(\mathrm{P}<0.05)$ with the dose of $(50,100 \mathrm{mg} / \mathrm{Kg}$,orally $)$ respectively in comparison to saline treated group $(0.0 \%)$, the high dose of tripotassiumdicitro bismuthate (III), is almost same as that of standard Sucralfate group (93.2\%) (Table1).

Table 1: Effect of tripotassiumdicitro bismuthate (III) complex and Sucralfate drug on ethanol induced gastric ulcer in rats.

\begin{tabular}{|c|c|c|c|c|}
\hline Treatment & $\begin{array}{c}\text { Dose } \\
\mathbf{m g} \backslash \mathbf{~ k g}\end{array}$ & No of rats & Ulcer index & \% Protection \\
\hline Control (Saline ) & & 5 & $28.72 \pm 7.9$ & 0.0 \\
\hline $\begin{array}{c}\text { Sucralfate } \\
\begin{array}{c}\text { tripotassiumdicitro } \\
\text { bismuthate } \\
\text { (III)complex }\end{array}\end{array}$ & 50 & 5 & $1.57 \pm 1.3^{*}$ & 93.2 \\
\hline $\begin{array}{c}\text { tripotassiumdicitro } \\
\text { bismuthate (III) } \\
\text { complex }\end{array}$ & 100 & 5 & $2.52 \pm 2^{*}$ & 91.2 \\
\hline
\end{tabular}

- Value is mean + SE 5 rats /group.

*Significantly different from the control group. $\mathrm{p}<0.05$. 
Bismuth compound have been used to treat gastrointestinal disorder since $18^{\text {th }}$ century (Scarpignato and Pelosini, 1999). The results of this study showed that the oral administration of tripotassiumdicitro bismuthate (III) prevent gastric mucosal injury caused by $\mathrm{HCl}$-ethanol. The most commonly employed test in the evaluation of antiulcer and cytoprotective activities (Konturek et al., 1998, Toma et al., 2005), the ability of the gastric mucosa to resist injury by endogenous secretion (acid, pepsin and bile ) and by ingested irritant (eg. Alcohol ) can be attributed to a number of factors that have been generally referred as mucosal defense (Wallace, 2001).

The formation of gastric mucosal lesion by necrotizing agents such as ethanol caused ulcer due to perturbation of superficial epithelial cells, notably the mucosal mast cell leading to the release of the vasoactive mediators including histamine, thus causing damage gastric mucosa (Miller and Henahan, 1984). Mucosal blood flow has been attributed to be an important factor in the damage caused by alcohol and is modulated by prostaglandin (Hollander et al., 1984), and generation of free radicals and the production of leukotriens (Toma et al., 2005, Glavi and Szabo, 1992).

The result show that tripotassiumdicitro bismuthate (III) probably exhibits gastroprotective action against ulcerogenic $\mathrm{HCl}$-ethanol because it has been found to stimulate mucosal generation and luminal release of PG it has been suggested that this protection mediated by $\mathrm{PG}$, and the cytoprotective effect of tripotassiumdicitro bismuthate (III) observed in this study which could be attributed to the endogenous generation of PG , was responsible for maintaining the cellular integrity of the gastric epithelium, therefore, such endogenous release of PG would play a physiological role in protecting the gastric mucosa. (Robert et al., 1984; Pugh and Lewin, 2008).

Bismuth compounds (Fraser, 2004) have antibacterial properties, and used successfully in the treatment of Helicobacter pylori induce ulcer (Larsen et al., 2003). In addition to the bactericidal properties, bismuth has also shown to decrease mucin viscosity, prevent bacterial digestion of mucus, and reduce adherence of bacterial to gastric epithelium cells (Larsen et al., 2003), as well as the bismuth drugs, speed the ulcer healing by affecting the binding of epidural growth factor to its receptor sites in the gastric mucosa (Konturek et al., 1988) and epidural growth factor accumulated in the ulcer area also has been growth promoting action that accelerates ulcer healing similar to that of gastrin (Takeuchi and Johson, 1986). All these properties characterize that bismuth drugs used for treatment erosive ulcers in gastrointestinal tract (Maev et al., 2008).

\section{Histological study}

Pretreatment with potassiumdicitro bismuthate (III) complex at $(50,100 \mathrm{mg} / \mathrm{Kg}$, orally) completely protects the gastric mucosa against different histological changes (congestion, hemorrhage, edema, necrosis, inflammatory change, erosion and ulceration) caused in $\mathrm{HCl}$-ethanol treated rats (Table 2 ).

These results were further supported by histopathological changes in the form of congestion, hemorrhage, edema, necrosis, inflammatory change, erosion and ulceration caused by the destructive stimuli in the gastric tissue, this confirms the cytoprotective ability of the tripotassiumdicitro bismuthate (III) complex which may be attributed to its selective binding to the ulcer base to form a protective barrier against acid - pepsin attack and to the enhancement of the re epithelialisation of the ulcerated mucosa (Wrkis et al., 1982). 
Table 2: The effect of potassiumdicitro bismuthate (III) complex potassium dicitro bismuthate (III)x on ethanol-HCl induced histopathological lesions in gastric mucosa

\begin{tabular}{|c|l|l|l|l|l|l|}
\hline \multirow{2}{*}{ Treatment } & \multicolumn{6}{|c|}{ Histopathological lesions } \\
\cline { 2 - 7 } & Ulceration & Edema & Necrosis & Congestion & $\begin{array}{c}\text { Inflammatory } \\
\text { change }\end{array}$ & Erosions \\
\hline Control & - & - & - & - & - & - \\
\hline (ethanol-HCl) & ++ & + & + & +++ & + & ++ \\
\hline $\begin{array}{c}\text { Tripotassiumdicitro } \\
\text { bismuthate complex } \\
\text { 50mg/Kg orally }\end{array}$ & - & - & - & - & - & - \\
\hline
\end{tabular}

$(-)$ Normal, $(+)$ moderate effect, $(++)$ sever effect, $(+++)$ intensely sever effect.

\section{CONCLUSION}

Over all, The obtained results demonstrate that potassiumdicitro bismuthate (III) complex display a good anti-ulcer activity, this protective effect might be have been mediate by both cytoprotective mechanisms and the compound have ability to restore mucosal PG to normal levels, thereby mediating PG dependent mechanism might play some role in the healing of chronic peptic ulcer.

\section{ACKNOWLEDGEMENT}

The author thank to Dr. Ghada / Dentistry College, Dr. Hafeth /Veterinary College, for his assistance in histological experiment, and to Dr. Cleveland J. Dodge, Brookhaven National Laboratory, USA for assistance in discussed infrared spectra.

\section{REFERENCES}

Abay, S.; Abdulwahib, M. (2008). Gastro protective effect of hydroalcoholic extract of rute chalepensis leaves. Pharmacogenosy Mag , 4 (16) (suppl) : S231-S233.

Ali, S.; Farhad G.; Hosein, S.; Monika; W.; Thorsten, G.; Reinhard, S. (2008). Chemical synthesis of nanocrystalline magnesium aluminate spinel via nitrate-citrate combustion route, J. Alloys and Compounds, 462, 1-2, 25, 142-146.

Alkofahi, A.; Atta, A. (1999). Pharmacological screening of the antiulcerogenic effects of some Jordanian Medicinal plants in rats . J. Ethanopharmacol, 65, 341-345.

Al-Howiriny, T.; Al-Sohaibani, M.; Al-Said, M.; Al-Yahya, M.; El-Tahir, K.; Rafatullah, S. (2005). Effect of commiphora opobalsamum (L.) Engl. (Balessan) on experimental gastric ulcers and secretion in rats. J. Ethnopharmacol, 98, 287-94.

Bighett, A.; Antonio, M.; Kohn, L.; Rehder, V.; Foglio, M.; Possenti, A.; Vilela L.; Carvalho, J. (2005). Antiulcerogenic activiyy of a crude hydroalcoholic extract and cumarin isolated from Mikania Laevigata Schultz Bip . Phytomedicine, 12, 72-77.

Carla, S.; Marcos, T.; Patrícia, V.; Fátima, F.; José, A. P.; Letícia , E.; Albino, B.; Federico, F.; Rosa , M. S.; Paula, B. A. (2008). Inflorescences of Brassicacea species as source of bioactive compounds: A comparative study Food Chemistry, 110 (4), 953-961. 
Coghill, S. ; Shepherd, A. (1988). A novel means of comparing the bioequivalence of two formulation of tripotassium dicitro bismuthate ( De-Noltab ) . Postgrad Med J., 64, 756.

Dimitr S. Todorovsky,a, Desislava G. Dumanova,a Rumiana V. Todorovska,b and Miroslava M. Getsovaa(2002). Preparation and Characterization of Yttrium-iron Citric Acid Complexes, CROATICA CHEM. ACTA CCACAA,75, (1) 155-164

Fraser, A . (2004). Helicobacter pylori : A historical perspective 1983- 2003 N. Z. Med. J. 117, U896.

Glavi, G.; Szabo, S. (1992). Experimental gastric mucosal injury : Laboratory models reveal mechanism of pathogenesis and new Therapeutic strategies . Federation of American Societies for Experimental boil. J. , 6, 825-831.

Govindarajan, R.; Vijayakumar, M.; Singh, M.; Rao, V.; Shirwarkar, A.; Rawat, A. (2006). Antiulcer and antimicrobial activity of Anogeissus latifolia . J. Ethanopharmacol . 106, 57-61.

Hollander, D.; Tarnawski, A.; Gergely, H.; Zipser, R. (1984). Sucralfate protection of the gastric mucosa against ethanol induced injury: A prostaglandin mediated process Scand J. Gastroenterol. Supplement, 19, 97-102.

Konturek, S.; Dembinski, A.; Wazecha, Z. (1988). Epidural growth factor ( EGF)in the gastro protective and ulcer healing action of colloidal bismuth subcitrate ( De-Nol) in rats. Physiol. Aca. Med. , 29, 894- 902.

Larsen, A.; Martiny, M.; Stoltenberg, G.; Danscher, J. (2003). Gastrointestinal and systemic uptake of bismuth in rat after oral exposure . Pharmacol. Toxicol, 93, 82- 90 .

Lima, Z.; Severi, J.; Pellizon, C.; Brito, A.; Solis, P.; Caceres, A. (2006). The aqueous decoction of mango flower be used as an antiulcer agent. J. Ethanopharmacol, 106(1), 29-37.

Lourence, L.B. ; Keith, L.P. (2008). "Manual of Pharmacology and Therapeutic". Copyright. McGraw - Hill Companies , 628p.

Malairajan, P.; Gopalakrishman, G.; Narasimhan , S. ; Jess Kala Veni, K. (2008). Evaluation of antiulcer activity of polyalthia Lonifolia (sonn), Thwaites in experimental animals , 40, 126-128.

Maria, K.; Catherine, G.; Catherine, P. R.; Aris, T.; Athanasios, S. (2008). pH-specific synthesis, isolation, spectroscopic and structural characterization of a new dimeric assembly of dinuclear vanadium (V)-citrate-peroxo species from aqueous solutions, Inorg. Chim. Acta, 361, 9-10, 27, 2631-2640.

Maev, I.; Samsonov, A.; Golubev, N. (2008). Bismuth preparation in the treatment of patients with gastric and duodenal ulcer disease, Klin Med (Mosk), 86(9), 57- 63 .

Miller, T.; Henahan, (1984). Indomethacin decrease resistance of gastric barrier to disruption by alcohol . Dig. Dis. Sci. 29(2), 141-149.

Nwafor, K.; Effraim, K.; Jacks, T. (1996). Gastro protective effects of aqueous extract of Khaya senegalensis bark on indomethacin induced ulceration in rats, West Afr. J. Pharmacol. Drug Research, 12, 46-50.

Peskar, B.; Maricic, N. (1998). Role of prostaglandins in gastro protection. Dig. Dis. Sci., 43, S 9-23. 
Petrova, N.; Todorovsky, D.; Mitov, I.; Tyuliev, G. (2008). Synthesis and characterization of yttrium-aluminum-iron and yttrium-cerium-iron citric complexes, $J$. Rare Earths, 26(3), 307-314.

Pugh, S.; Lewin, M. (2008). Mechanism of action of Roter ( bismuthate subnitrate) in patients with duodenal ulcer disease and healthy volunteers, Gastroenterology and Hepatology, 382-386.

Robert, A.; Nezamis, J. ; Davis, J.; Field, S.; Hanchar, A. (1983). Mild irritants prevent gastric necrosis Through adaptive cytoprotective mediated by prostaglandins. Am. J. Physiol. , 245, G113-G121.

Scarpignato, C.; Pelosini, I. (1999). Bismuth compound for eradication of Helicobacter pylori : Pharmacology and safty . Prog. Basic Clin. Pharmacol. 11, 87- 127.

Singh, R.; Madan, J.; Rao H. (2008). Antiulcer activity of black piper against absolute ethanol induced gastric mucosal damage in rat. Phacog. Mag ., 15, 232-235.

Toma, W.; Hiruma, L.C.; Guerrero, R.; Souza, A. (2005). Preliminary studies of Mammea Americana L ( Gutti Ferae) bark $\backslash$ latex extract point to an effective antiulcer effect on gastric ulcer models in rat, Phytomedicine, 12, 345-350.

Tselesh, A. S. (2008). Anodic behaviour of tin in citrate solutions: The IR and XPS study on the composition of the passive layer, 516(18), (31), 6253-6260.

Wallace, J. (2001). Mechanisms of protection and healing: Current knowledge and future research. American J. l Medecine, 110, 19S-22S.

Takeuchi; Johson, L. (1986). Effect of cell proliferation on healing of gastric and duodenal ulcer in rats . Digestion. 33, 92-101.

Wrkis, J.; Hespe, W.; Jaity, K. D.; Knockkoch, P.; Lavy, U. (1982). Pharmacolgical properties of colloidal bismuth subcitrate.1982, Scand J. Gastroenterol, suppl. 80 (17), 11-16.

Wagstaff, A. ; Benfield, P.; Monk, J. (1988). Colloid bismuth subcitrate : A review of its pharmacodynamic and pharmacokinetic properties, and its therapeutic use in peptic ulcer disease. Drug 36, 132- 198. 